\title{
BIOACCUMULATION OF METALS IN DIFFERENT SPECIES OF MULBERRY
}

Saša S. Randjelović, Danijela A. Kostić, Biljana B. Arsić, Gordana Stojanović

University of Niš, Faculty of Science and Mathematics, Department of Chemistry, Niš, Serbia

The concentrations of $\mathrm{Zn}, \mathrm{Mn}, \mathrm{Fe}, \mathrm{Pb}, \mathrm{Ni}, \mathrm{Cu}$ and $\mathrm{Cd}$ in soil, leaves and mulberry fruits (Morus alba L. and Morus nigra L.) from southeast Serbia were determined by atomic absorption spectroscopy. Metal translocations from soil to fruit were calculated, as well as their oral intake and health risk indices. Positive correlations were found among metal concentrations in soil, leaves and fruit.
(ORIGINAL SCIENTIFIC PAPER) UDC 546.3:582.635.3:543.4

Keywords: mulberry fruits, soil metal, leaves metal, plant metal

\section{Introduction}

Metals found in surface soil derive from rock and precipitation. Urban areas contain more anthropogenic metals due to higher population density, traffic intensity, and proximity to industry. Their long-term deposition may reduce soil buffering capacity and cause soil and groundwater contamination [1]. Fruits accumulate soil metals during growth and processing. As metals are not biodegradable they may accumulate up the food chain. Although some are micronutrients, in high concentrations they are toxic [2]. The increased environmental heavy metal concentrations may lead to the increased human intake, causing serious illness [3-7]. Zinc, copper, iron, chromium and cobalt are essential and become toxic only in high concentrations, while lead and cadmium are highly toxic [8]. It is thus important to monitor metals in soil, fruit and fruit products. Many species of fruit used in nutrition and folk medicine grow in southeast Serbia.

Mulberry belongs to the genus Morus of the Moraceae family. Although it is extensively grown as food for silkworms in many countries, the mulberry fruit production is the main aim in Turkey, which is one of the most important mulberry fruit producers in the world $[9,10]$. Mulberry is found from temperate to subtropical regions of the northern hemisphere to the tropics of the southern hemisphere and it can grow in a wide range of climatic, topographical and soil conditions. It is widely spread throughout all regions from the tropics to the subartic areas. Genus Morus is widespread in Asia, Europe, North and South America and Africa as well. Mulberry has a unique delicious fruit of the sour and refreshing taste. It has been used as a folk remedy to treat oral and dental diseases, diabetes, hypertension, arthritis and anemia [11]. The bright black and purple mulberry fruits, which have a very pleasant taste when eaten fresh, are also used in jams, juices, liquors, natural dyes, as well as in the cosmetics industry [12]. Morus species are deciduous and in the period of low temperatures during the winter they are required to break dormancy. Mulberry fruits may be of white, red or black colour when they are ripe. Deepcoloured fruits are good sources of phenolics including flavonoids, anthocyanins and carotenoids [13-16], and mulberries are rich in phenolics [17].

Fruits and their extracts deserve special attention because of the important influence they have on human health. For the majority of the world population, fruits represent the primary source of the health care. Although the effectiveness of fruits is mainly associated with their constituents such as essential oils, vitamins, glycosides, etc., it was found that a prolonged intake can cause health problems due to the possible presence of heavy metals [3].

Mulberry fruit and leaves (Morus alba L. and Morus nigra L.) from rural southeast Serbia were analyzed (Table 1). Metals uptake from soil to leaves and fruit was determined. The health risk index estimates the risk due to the exposure.

\section{Experimental}

\section{Reagents}

All chemicals were of analytical grade. High purity deionized water (conductivity $0.05 \mu \mathrm{S} \mathrm{cm}^{-1}$ ) was used in the solution preparation. Stock $\mathrm{Cu}, \mathrm{Mn}, \mathrm{Zn}, \mathrm{Fe}, \mathrm{Pb}, \mathrm{Ni}$ and $\mathrm{Cd}$ solutions $\left(1 \mathrm{~g} \mathrm{~L}^{-1}\right)$ were purchased from Merck (Darmstadt, Germany).

\section{Sample preparation}

Sampling points were selected by a standard procedure [18]. Points were at least $300 \mathrm{~m}$ from the main road, $100 \mathrm{~m}$ from the local road, and $5 \mathrm{~m}$ from the forest road to avoid pollution from vehicle exhaust. The samples were collected in southeast Serbia (locations in Table 3)

\footnotetext{
*Author address: Danijela Kostić, Faculty of Sciences and Mathematics, Department of Chemistry, University of Niš, 33 Višegradska Street, 18000 Niš, Serbia

E-mail: danijelaaakostic@yahoo.com

The manuscript received: November, 12, 2014.

Paper accepted: December, 01, 2014.
} 
during July 2014. Fruit and leaves were collected from the same plants. The soil sampling followed a zigzag principle at the depth of $0-30 \mathrm{~cm}$.

\section{Soil analysis}

Air-dried soil samples were oven dried at $105^{\circ} \mathrm{C}$ for two hours, then ground to pass through $2 \mathrm{~mm}$ sieves. Ten grams of the sample was suspended in deionized water in a $100 \mathrm{~mL}$ volumetric flask then filtered through Whatman No. 42 filter paper. The $\mathrm{pH}$ of the first $25 \mathrm{~mL}$ of the filtrate was measured. The remaining $75 \mathrm{~mL}$ was evaporated to dryness on a water bath, dissolved in $5 \mathrm{~mL}$ of $1: 1 \mathrm{HNO}_{3}: \mathrm{H}_{2} \mathrm{O}$ plus $5 \mathrm{~mL}$ of $1: 1 \mathrm{HCl}: \mathrm{H}_{2} \mathrm{O}$, then diluted to $25 \mathrm{~mL}$ [18].

\section{Fruit and leaves analysis}

The fruit and leaves were washed with distilled water to remove dust and parasites, dried at $105^{\circ} \mathrm{C}$ for $24 \mathrm{~h}$, and homogenized [18]. The standard AOAC (2000) sample preparation was followed [18]. The accurately weighed $(1 \mathrm{~g})$ sample in a silica crucible was ashed in a muffle furnace at $450{ }^{\circ} \mathrm{C}$ for $2 \mathrm{~h}$ and then $5 \mathrm{~mL}$ of $6 \mathrm{M} \mathrm{HCl}$ was added. Care was taken to ensure that all the ash came into contact with the acid. The sample was digested on a hot plate to obtain a clear solution. The residue was dissolved in $0.1 \mathrm{M} \mathrm{HNO}_{3}$ and made up to $25 \mathrm{~mL}$. Working standards were prepared by diluting stock solutions with $0.1 \mathrm{M}$ nitric acid. The blank was deionized water.

\section{Apparatus}

Air-acetylene flame atomic absorption measurements were made using a Varian SpectrAA 20 spectrophotometer. Working conditions and limits of detection are shown in Table 1. Hanna Instruments $\mathrm{pH}$ meter was used to measure $\mathrm{pH}$. Sigma $\mathrm{pH} 7,00 \pm 0,01$ and 4,00 $\pm 0,01$ calibration buffers were used. Milli-Q apparatus prepared high purity deionized water.

Table 1. Working coditions and limits of detection

\begin{tabular}{lccccc}
\hline \multicolumn{1}{c}{ Metal } & $\begin{array}{c}\text { Calibration } \\
\text { range } \\
(\mathrm{mg} / \mathrm{l})\end{array}$ & $\begin{array}{c}\text { Limit of detection } \\
(\mathrm{LOD})(\mathrm{mg} / \mathrm{l})\end{array}$ & $\begin{array}{c}\text { Wavelength } \\
(\mathrm{nm})\end{array}$ & Slit (nm) & $\begin{array}{c}\text { Acetylen } \\
\text { flow }(\mathrm{I} / \mathrm{min})\end{array}$ \\
\hline Iron (Fe) & $0,00-10,00$ & 0,015 & 248,3 & 0,2 & 2,0 \\
Copper (Cu) & $0,00-1,00$ & 0,007 & 324,8 & 1,0 & 1,8 \\
Zink (Zn) & $0,00-5,00$ & 0,021 & 213,9 & 0,5 & 2,0 \\
Lead (Pb) & $0,00-1,00$ & 0,002 & 217,0 & 1,0 & 1,6 \\
Cadmium (Cd) & $0,00-1,00$ & 0,003 & 228,8 & 0,5 & 2,0 \\
Manganese (Mn) & $0,00-2,00$ & 0,005 & 279,5 & 0,2 & 1,8 \\
Nickel (Ni) & $0,00-1,00$ & 0,002 & 232,0 & 0,2 & 2,0 \\
\hline
\end{tabular}

Data analysis

Calculation of oral intake of metals from soil through fruits

The daily intake of metals (DIM) from fruit was estimated following Jolly et al. [19].

DIM = daily fruit consumption $\times$ mean fruit metal concentrations ( $\mathrm{mg}$ day $^{-1}$, fresh weight).

The daily fruit consumption was assumed to be $300 \mathrm{~g}$ per person [20].

Calculation of the health risk index of metal contamination of fruits

Health risk was characterized by a Hazard Quotient (HQ) [21], the ratio between the exposure and the reference oral dose (RfD).

$H Q=D I M / R f D$.

Where RfD is the oral reference dose for metal (mg day $^{-1}$ ) assuming $70 \mathrm{~kg}$ bodyweight. If $\mathrm{HQ}$ is less than 1 there will be no obvious risk. Although the $\mathrm{HQ}$ does not quantitatively estimate the probability of negative health effects, it provides an indication of the health risk [19].

\section{Results and discussion}

Metal concentration in soil, leaves and fruit

Results of of $\mathrm{Zn}, \mathrm{Mn}, \mathrm{Fe}, \mathrm{Cu}, \mathrm{Pb}, \mathrm{Ni}, \mathrm{Cu}$ and $\mathrm{Cd}$ determinations in soil, leaves and fruit are shown in Table 2. The iron content was several times higher than that of other metals, ranging from 18569,7 to $27987,7 \mathrm{ppm}\left(\mathrm{mg} \mathrm{kg}^{-1}\right)$ in soil, 115,097 to $206,63 \mathrm{ppm}$ in leaves, and 9,57 to $26,89 \mathrm{ppm}$ in fruit. The maximum Fe set by FAO/WHO (1984) [22] in edible plants is 20 ppm. However, for medicinal plants WHO limits have not been established [23].

Zinc is important in protein synthesis enzymes, energy production, and in maintaining membranes. $\mathrm{Zn}$ concentrations ranged from 40,02-125,78 ppm in soil, 18,65-55,37 ppm in leaves, and 1,369-7,18 ppm in fruit. According to the literature data [24], soil Zn levels should not be greater than 200-300 ppm. For a majority of species, the symptoms of zinc deficiency appear with leaf concentrations of 20-30 ppm. However, all Zn levels we found were below those in literature. The FAO/WHO limit (1984) is 27,4 ppm Zn in edible plants. [22]

Mn varies from 108,92 to $162,04 \mathrm{ppm}$ in soil, from 37,03 to 93,52 ppm in leaves and from 3,03 ppm (Morus alba L., "Mokra") to 8,97 ppm (Morus nigra., "Pukovac") in fruit. The FAO/WHO Mn limit in edible plants is $2 \mathrm{ppm}$. [22]

Copper ranges from 20,37 (Morus alba L., Aleksinac) to 40,0 (Morus alba L., Mokra) ppm in soil, 4,33-16,52 ppm in leaves, and 1,06-2,586 ppm in fruit. According to Allaway $\mathrm{Cu}$ in agricultural products should be between 4 and 15 ppm, and FAO/WHO (1984) recommends 3.00 ppm or less. [25, 22] 
Table 2. Mean metal concentrations in soil, leaves and fruit

\begin{tabular}{|c|c|c|c|c|c|c|c|c|c|}
\hline Location & Fruit & Sample & $\begin{array}{c}\mathrm{Fe} \\
\mathrm{mg} / \mathrm{kg}\end{array}$ & $\begin{array}{c}\mathrm{Zn} \\
\mathrm{mg} / \mathrm{kg}\end{array}$ & $\begin{array}{c}\mathrm{Cu} \\
\mathrm{mg} / \mathrm{kg}\end{array}$ & $\begin{array}{c}\mathrm{Mn} \\
\mathrm{mg} / \mathrm{kg}\end{array}$ & $\begin{array}{c}\mathrm{Ni} \\
\mathrm{mg} / \mathrm{kg}\end{array}$ & $\begin{array}{c}\mathrm{Pb} \\
\mathrm{mg} / \mathrm{kg}\end{array}$ & $\begin{array}{c}\mathrm{Cd} \\
\mathrm{mg} / \mathrm{kg}\end{array}$ \\
\hline \multirow{6}{*}{ Pukovac } & \multirow{3}{*}{$\begin{array}{l}\text { Morus } \\
\text { alba } L .\end{array}$} & Soil & $20153,10 \pm 403$ & $52,53 \pm 1,05$ & $32,57 \pm 0,65$ & $156,96 \pm 3,14$ & $9,45 \pm 0,19$ & - & $0,55 \pm 0,01$ \\
\hline & & Leaves & $160,84 \pm 3,22$ & $40,96 \pm 0,82$ & $7,55 \pm 0,151$ & $90,01 \pm 1,80$ & - & - & - \\
\hline & & Fruit & $12,33 \pm 0,25$ & $3,56 \pm 0,07$ & $1,06 \pm 0,02$ & $5,13 \pm 0,10$ & - & - & - \\
\hline & \multirow{3}{*}{$\begin{array}{c}\text { Morus } \\
\text { nigra L. }\end{array}$} & Soil & $19895,20 \pm 397$ & $71,12 \pm 1,42$ & $28,65 \pm 0,53$ & $130,25 \pm 2,61$ & $10,36 \pm 0,21$ & - & $0,63 \pm 0,01$ \\
\hline & & Leaves & $143,87 \pm 2,88$ & $42,37 \pm 0,85$ & $5,69 \pm 0,11$ & $81,59 \pm 1,63$ & - & - & - \\
\hline & & Fruit & $10,36 \pm 0,21$ & $3,56 \pm 0,07$ & $1,52 \pm 0,03$ & $8,96 \pm 0,18$ & - & - & - \\
\hline \multirow{6}{*}{ Mokra } & \multirow{3}{*}{$\begin{array}{l}\text { Morus } \\
\text { alba L. }\end{array}$} & Soil & $22136,50 \pm 442$ & $81,69 \pm 1,64$ & $40,06 \pm 0,80$ & $125,67 \pm 2,51$ & $6,35 \pm 0,13$ & $4,67 \pm 0,09$ & $0,87 \pm 0,01$ \\
\hline & & Leaves & $183,82 \pm 3,68$ & $22,72 \pm 0,45$ & $9,47 \pm 0,19$ & $84,71 \pm 1,69$ & - & - & - \\
\hline & & Fruit & $15,82 \pm 0,32$ & $7,18 \pm 0,14$ & $1,90 \pm 0,04$ & $3,03 \pm 0,06$ & - & - & - \\
\hline & \multirow{3}{*}{$\begin{array}{c}\text { Morus } \\
\text { nigra L. }\end{array}$} & Soil & $19862,20 \pm 398$ & $125,77 \pm 2,52$ & $36,89 \pm 0,74$ & $109,43 \pm 2,19$ & $6,72 \pm 0,13$ & $5,38 \pm 0,11$ & $0,91 \pm 0,02$ \\
\hline & & Leaves & $115,09 \pm 2,31$ & $55,37 \pm 1,11$ & $7,51 \pm 0,15$ & $37,03 \pm 0,74$ & - & - & - \\
\hline & & Fruit & $26,89 \pm 0,54$ & $5,48 \pm 0,11$ & $1,56 \pm 0,03$ & $4,38 \pm 0,09$ & - & - & - \\
\hline \multirow{6}{*}{ Svrljig } & \multirow{3}{*}{$\begin{array}{l}\text { Morus } \\
\text { alba L. }\end{array}$} & Soil & $19985,30 \pm 399$ & $45,78 \pm 0,92$ & $26,21 \pm 0,52$ & $162,04 \pm 3,25$ & $10,25 \pm 0,20$ & $1,00 \pm 0,02$ & $0,39 \pm 0,01$ \\
\hline & & Leaves & $120,56 \pm 2,42$ & $26,85 \pm 0,54$ & $6,52 \pm 0,13$ & $93,52 \pm 1,87$ & - & - & $0,20 \pm 0,01$ \\
\hline & & Fruit & $9,57 \pm 0,19$ & $1,37 \pm 0,03$ & $1,14 \pm 0,02$ & $8,55 \pm 0,17$ & - & - & $0,12 \pm 0,01$ \\
\hline & \multirow{3}{*}{$\begin{array}{l}\text { Morus } \\
\text { nigra L. }\end{array}$} & Soil & $18569,70 \pm 371$ & $40,02 \pm 0,80$ & $21,5 \pm 0,43$ & $148,21 \pm 2,96$ & $9,96 \pm 0,20$ & $0,97 \pm 0,02$ & $0,41 \pm 0,01$ \\
\hline & & Leaves & $131,56 \pm 2,63$ & $18,65 \pm 0,37$ & $4,32 \pm 0,08$ & $72,57 \pm 1,45$ & - & - & $0,22 \pm 0,01$ \\
\hline & & Fruit & $10,26 \pm 0,20$ & $2,99 \pm 0,06$ & $1,87 \pm 0,04$ & $5,96 \pm 0,12$ & - & - & $0,13 \pm 0,01$ \\
\hline \multirow{6}{*}{ Aleksinac } & \multirow{3}{*}{$\begin{array}{l}\text { Morus } \\
\text { alba L. }\end{array}$} & Soil & $26895,60 \pm 537$ & $70,25 \pm 1,41$ & $20,36 \pm 0,41$ & $130,05 \pm 2,60$ & $12,54 \pm 0,25$ & - & $0,50 \pm 0,01$ \\
\hline & & Leaves & $200,77 \pm 4,01$ & $30,26 \pm 0,60$ & $16,52 \pm 0,33$ & $60,20 \pm 1,20$ & - & - & - \\
\hline & & Fruit & $19,39 \pm 0,39$ & $2,24 \pm 0,04$ & $2,59 \pm 0,05$ & $5,20 \pm 0,10$ & - & - & - \\
\hline & \multirow{3}{*}{$\begin{array}{l}\text { Morus } \\
\text { nigra L. }\end{array}$} & Soil & $27987,70 \pm 559$ & $56,37 \pm 1,13$ & $22,05 \pm 0,44$ & $108,92 \pm 2,18$ & $11,22 \pm 0,22$ & - & $0,52 \pm 0,01$ \\
\hline & & Leaves & $206,63 \pm 4,13$ & $28,99 \pm 0,58$ & $15,23 \pm 0,30$ & $44,53 \pm 0,89$ & - & - & - \\
\hline & & Fruit & $23,00 \pm 0,46$ & $2,69 \pm 0,05$ & $1,96 \pm 0,04$ & $4,96 \pm 0,10$ & - & - & - \\
\hline
\end{tabular}

Cadmium was $0,502-0,907$ ppm in soil, 0,00-0,225 ppm in leaves and in fruit it was below the detection limit. Maobe et al. report FAO/WHO cadmium limits of $0.21 \mathrm{ppm}$ in edible plants. [26] However, for medicinal herbs WHO, Canada, China and Thailand allow 0.3 ppm cadmium. Canadian cadmium limits in finished herbal products are $0.006 \mathrm{mg} \mathrm{day}^{-1} .[27]$

Table 3. Contents of metal concentrations in soil, leaves and fruit from different countries

\begin{tabular}{|c|c|c|c|c|c|c|c|c|c|}
\hline \multirow{2}{*}{ Location } & \multirow{2}{*}{ Sample } & \multicolumn{7}{|l|}{ Metal } & \multirow{2}{*}{ References } \\
\hline & & $\mathrm{Fe}$ & $\mathrm{Zn}$ & $\mathrm{Cu}$ & $\mathrm{Mn}$ & $\mathrm{Pb}$ & $\mathrm{Cd}$ & $\mathrm{Ni}$ & \\
\hline \multirow{2}{*}{$\begin{array}{l}\text { Northwestern } \\
\text { Romania }\end{array}$} & Soil & & & $66,3-38,1$ & & $108-397$ & $0,48-3,12$ & & \multirow[b]{2}{*}{ [25] } \\
\hline & Plant & & & $2,64-9,55$ & & $0,26-3,24$ & $0,09-4,21$ & & \\
\hline \multirow{2}{*}{$\begin{array}{l}\text { Mining region, } \\
\text { Canada }\end{array}$} & Soil & 447,01 & 1,65 & 115,25 & & & & & \multirow{2}{*}{ [28] } \\
\hline & Leaves & 906,81 & 29,53 & 65,78 & & & & & \\
\hline \multirow{2}{*}{ Pakistan } & Soil & $245,99-324,76$ & $17,81-93,19$ & $4,98-71,89$ & $111,04-7,62$ & $2,08-16,57$ & $0,15-1,99$ & $3,90-23,53$ & \multirow{2}{*}{ [29] } \\
\hline & Plant & $33,77-79,6$ & $8,37-47,71$ & $4,93-17,67$ & $3,15-84,73$ & $1,09-6,04$ & $0,00-1,48$ & $0,81-14,73$ & \\
\hline \multirow{3}{*}{ Mexico } & Soil & $3,56-74,228$ & & $0,588-35,808$ & $15,214-9,844$ & $0,562-85,656$ & $0,013-5,036$ & & \multirow{3}{*}[30]{} \\
\hline & Plant & $766,66-25359,6$ & $31,13-849,74$ & $69,87-213,63$ & $\mathrm{Na}-485,14$ & $\mathrm{Nd}-293,24$ & & & \\
\hline & PUF & $0,07-0,91$ & $0,61-2,86$ & $0,94-1,91$ & $\mathrm{Nd}-1,52$ & $\mathrm{Nd}-0,21$ & & & \\
\hline \multirow[b]{2}{*}{ West Algeria } & Soil & $4030-9390$ & $21,15-731,08$ & $4,32-15,32$ & $79,03-244,94$ & $7,99-39,14$ & $1,89-10,18$ & $7,99-39,14$ & \multirow[b]{2}{*}{ [31] } \\
\hline & Plant & $220-1690$ & $432,15-918,89$ & $38,14-44,97$ & $56,52-73,72$ & $5,42-28,47$ & $2,24-6,15$ & $5,42-28,47$ & \\
\hline \multirow{2}{*}{ Nigeria } & Soil & $0,27-0,63$ & $0,30-0,40$ & $0,34-0,91$ & & $0,10-0,53$ & $0,32-0,84$ & $0,21-0,42$ & \multirow{2}{*}{ [32] } \\
\hline & Leaves & $0,02-0,32$ & $0,02-0,06$ & $0,06-0,49$ & & $\mathrm{Nd}-0,07$ & $0,02-0,43$ & $0,01-0,02$ & \\
\hline \multirow{2}{*}{ Dunhua, China } & Soil & & & & & $18,57-110,82$ & $0,9-1,76$ & & \multirow{2}{*}{ [33] } \\
\hline & Leaves & & & & & 0,209 & 1,133 & & \\
\hline \multirow{3}{*}{ Turkey } & Soil & & $295,4-330,7$ & $184,7-217,5$ & $436,8-527,3$ & $76,6-500,2$ & $16,96-6,45$ & $1,73-4,24$ & \multirow{3}{*}{ [34] } \\
\hline & Leaves & & $18,23,88$ & $6,38-8,26$ & $234-354,4$ & $0,86-1,28$ & $0,92-2,02$ & $0,03-0,06$ & \\
\hline & Plant & & $5,97-8,74$ & $2,12-3,14$ & $74,1-127,2$ & $0,28-0,47$ & $0,30-0,75$ & $0,01-0,02$ & \\
\hline \multirow{3}{*}{ Iraq } & Soil & $0.003-26 \%$ & & & & $29-183$ & $105-208$ & $11-41$ & \multirow{3}{*}{ [35] } \\
\hline & Leaves & $56316 \mathrm{ppm}$ & & & & $20-47$ & $27-475$ & $11-20$ & \\
\hline & Plant & $75-711$ & & & & $21-48$ & $30-127$ & $10-22$ & \\
\hline
\end{tabular}

Nickel was detected in soil $(6,351-12,54 \mathrm{ppm})$. It was detected neither in leaves nor fruit. Maobe et al. [26] report $\mathrm{FAO} / \mathrm{WHO} \mathrm{Pb}$ limits in edible plants of $1,63 \mathrm{ppm}$.

Other authors have presented similar findings. The results are represented in Table 3. 
Soil metals in northwestern Romania vary from 66,3 to $238,1 \mathrm{ppm}(\mathrm{Cu}), 108-397 \mathrm{ppm}(\mathrm{Pb})$, and 0,48 to $3,12 \mathrm{ppm}$ (Cd). Plant metal concentrations from this area are 2,64 to $19,55 \mathrm{ppm}(\mathrm{Cu}), 0,26$ to $3,24 \mathrm{ppm}(\mathrm{Pb})$ and 0,09 to $4,21 \mathrm{ppm}(\mathrm{Cd})$ [25].

Soil metals uptake to leaves and fruit

Plant uptake of trace metals depends on soil pH, soil organics, and soil type, but the metals concentration in the soil is the dominant factor [36]. The relationships among metals concentrations in soil, foliage, and fruit may be summarized by species-specific plant uptake factors (PUF) which measure the efficiency of metal accumulation [37]. They are defined by:

PUFsf $=$ fruit concentration $/$ soil concentration

PUFsI = leaf concentration $/$ soil concentration

PUFIf = fruit concentration / leaf concentration

These factors are shown in Table 4.

Table 4. PUF values

\begin{tabular}{|c|c|c|c|c|c|c|c|c|c|}
\hline Location & Sample & PUF & $\mathrm{Fe}$ & $\mathrm{Zn}$ & $\mathrm{Cu}$ & $\mathrm{Mn}$ & $\mathrm{Ni}$ & $\mathrm{Pb}$ & $\mathrm{Cd}$ \\
\hline \multirow{6}{*}{ Pukovac } & \multirow{3}{*}{$\begin{array}{l}\text { Morus } \\
\text { alba L. }\end{array}$} & Soil/Leaves & 0,008 & 0,7797 & 0,2318 & 0,5734 & - & - & - \\
\hline & & Soil/Fruit & $6,1110^{-4}$ & 0,0678 & 0,0324 & 0,0327 & - & - & - \\
\hline & & Leaves/Fruit & 0,076 & 0,087 & 0,1399 & 0,1399 & - & - & - \\
\hline & \multirow{3}{*}{$\begin{array}{c}\text { Morus } \\
\text { nigra L. }\end{array}$} & Soil/Leaves & 0,0072 & 0,5958 & 0,1988 & 0,6264 & - & - & - \\
\hline & & Soil/Fruit & $5,2110^{-4}$ & 0,0500 & 0,0531 & 0,0688 & - & - & - \\
\hline & & Leaves/Fruit & 0,072 & 0,0839 & 0,2670 & 0,1099 & - & - & - \\
\hline \multirow{6}{*}{ Mokra } & \multirow{3}{*}{$\begin{array}{l}\text { Morus } \\
\text { alba L. }\end{array}$} & Soil/Leaves & 0,0083 & 0,2781 & 0,2365 & 0,6740 & - & - & - \\
\hline & & Soil/Fruit & $7,1510^{-4}$ & 0,0879 & 0,0475 & 0,0241 & - & - & - \\
\hline & & Leaves/Fruit & 0,0860 & 0,3160 & 0,2001 & 0,0356 & - & - & - \\
\hline & \multirow{3}{*}{$\begin{array}{c}\text { Morus } \\
\text { nigra L. }\end{array}$} & Soil/Leaves & 0,0058 & 0,4402 & 0,2037 & 0,3384 & - & - & - \\
\hline & & Soil/Fruit & 0,0013 & 0,0435 & 0,0423 & 0,0401 & - & - & - \\
\hline & & Leaves/Fruit & 0,0794 & 0,0989 & 0,2080 & 0,1184 & - & - & - \\
\hline \multirow{6}{*}{ Svrljig } & \multirow{3}{*}{$\begin{array}{l}\text { Morus } \\
\text { alba L. }\end{array}$} & Soil/Leaves & 0,0060 & 0,5865 & 0,2488 & 0,5772 & - & - & 0,5128 \\
\hline & & Soil/Fruit & $4,7910^{-4}$ & 0,0300 & 0,0436 & 0,0528 & - & - & 0,3211 \\
\hline & & Leaves/Fruit & 0,0794 & 0,051 & 0,1751 & 0,0915 & - & - & 0,6262 \\
\hline & \multirow{3}{*}{$\begin{array}{c}\text { Morus } \\
\text { nigra L. }\end{array}$} & Soil/Leaves & 0,0071 & 0,4661 & 0,2010 & 0,4896 & - & - & 0,5420 \\
\hline & & Soil/Fruit & $5,5210^{-4}$ & 0,0746 & 0,0869 & 0,0402 & - & - & 0,3289 \\
\hline & & Leaves/Fruit & 0,0779 & 0,1601 & 0,4323 & 0,0789 & - & - & 0,6067 \\
\hline \multirow{6}{*}{ Aleksinac } & \multirow{3}{*}{$\begin{array}{l}\text { Morus } \\
\text { alba L. }\end{array}$} & Soil/Leaves & 0,0074 & 0,4308 & 0,8112 & 0,4629 & - & - & - \\
\hline & & Soil/Fruit & $7,210^{-4}$ & 0,0318 & 0,1269 & 0,0400 & - & - & - \\
\hline & & Leaves/Fruit & 0,0965 & 0,0740 & 0,1565 & 0,0864 & - & - & - \\
\hline & \multirow{3}{*}{$\begin{array}{c}\text { Morus } \\
\text { nigra L. }\end{array}$} & Soil/Leaves & 0,0074 & 0,5144 & 0,6903 & 0,4088 & - & - & - \\
\hline & & Soil/Fruit & $8,210^{-4}$ & 0,0478 & 0,8881 & 0,0455 & - & - & - \\
\hline & & Leaves/Fruit & 0,1113 & 0,0931 & 0,1286 & 0,1113 & - & - & - \\
\hline
\end{tabular}

$\mathrm{Cd}, \mathrm{Cu}$ and $\mathrm{Zn}$ are more efficiently concentrated in leaves, while $\mathrm{Mn}$ and $\mathrm{Fe}$ are less so. $\mathrm{Cu}, \mathrm{Fe}$ and $\mathrm{Zn}$ accumulate more in fruit than in leaves, $\mathrm{Mn}$ and $\mathrm{Cd}$ much less so. Fe is deposited mostly in fruit.

Daily intake of metals from mixed fruit

Table 5. shows the approximate daily intake of metals from mixed fruit. These were calculated from the average of the fruit metals contents (Table 2), assuming a daily fruit consumption of $300 \mathrm{~g}$ [20]. As fruit is mostly water, and the analyses are reported on a dry weight basis, these estimates of the metal intake tend to be high. The metals intake is thus within recommended limits of various agencies [38-41].

Table 5. Estimated daily intake of metal (DIM) and potential health hazards (HQ) from fruit

\begin{tabular}{llllll}
\hline Metal & $\begin{array}{l}\text { Average fruit } \\
\text { concentration } \\
(\mathrm{mg} / \mathrm{kg})\end{array}$ & $\begin{array}{l}\text { Daily intake } \\
(\mathrm{mg} / \mathrm{kg})\end{array}$ & $\mathrm{R}_{\mathrm{f}} \mathrm{D}(\mathrm{mg} / \mathrm{day})$ & $\mathrm{HQ}$ & References \\
\hline $\mathrm{Zn}$ & 36,335 & 10,9005 & 15,00 & 0,728 & {$[19]$} \\
$\mathrm{Mn}$ & 5,7725 & 1,7317 & $0,5-5,0$ & 0,346 & {$[19]$} \\
$\mathrm{Fe}$ & 159,522 & 47,86 & $10,0-60,0$ & 0,798 & {$[19]$} \\
$\mathrm{Pb}$ & 0 & 0 & 0,245 & 0 & {$[42]$} \\
$\mathrm{Ni}$ & 0 & 0 & 1,400 & 0 & {$[43]$} \\
$\mathrm{Cu}$ & 1,7001 & 0,5100 & $2,0-3,0$ & 0,17 & {$[19]$} \\
$\mathrm{Cd}$ & 0,1302 & 0,0391 & 0,070 & 0,643 & {$[43]$} \\
\hline
\end{tabular}


Potential health hazards $(\mathrm{HQ})$

The hazard quotients $(\mathrm{HQ})$ represented in Table 5., for $\mathrm{Zn}, \mathrm{Mn}, \mathrm{Fe}, \mathrm{Pb}, \mathrm{Ni}$, Cu and Cd were 0,728; 0,346; 0,798; 0 ; $0 ; 0,17$ and 0,643 decreasing $\mathrm{Fe}>\mathrm{Zn}>\mathrm{Cd}>\mathrm{Mn}>\mathrm{Cu}>\mathrm{Pb}=\mathrm{Ni}$. The $H Q$ value for all the elements were below 1 , suggesting that fruit consumption is safe.

\section{Conclusion}

$\mathrm{Fe}, \mathrm{Zn}, \mathrm{Mn}, \mathrm{Cu}$ and $\mathrm{Cd}$ were determined in soil, leaves and fruit of mulberry (Morus nigra L. and Morus alba L.) from southeast Serbia. $\mathrm{Pb}$ and $\mathrm{Ni}$ were found in soil but not in leaves or fruit. The ratios among metals concentrations in soil, leaves and fruit were calculated. Strong correlations among the concentrations in soil, leaves and fruit were found.

The metal contents of Morus nigra L. and Morus alba L. pose no hazard to human health.

\section{Acknowledgments}

The financial support from the Ministry of Education, Science and Technological Development of the Republic of Serbia Project No: ON 172047 is gratefully acknowledged.

\section{References}

[1] M. Arora, B. Kiran, S. Rani, A. Rani, B. Kaur, N. Mittal, Heavy metal accumulation in vegetables irrigated with water from different sources, Food Chemistry, 111 (2008) $811-815$.

[2] A.O. Isiaka, O.A. Al Moaruf, O.B. Muibat, O.I. Asiata and O.O. Nureni, Heavy trace metals and macronutrients status in herbal plants of Nigeria, Food Chemistry, 85 (2004) 67 - 71.

[3] S. Jabeen, M.T. Shah, S. Khan, M.Q. Hayat, Determination of major and trace elements in ten important folk therapeutic plants of Haripur basin, Pakistan, Journal of Medicinal Plants Research, 4 (2010) 559-566.

[4] S.A. Khan., L. Khan, I. Hussain, K.B. Marwat, N. Akhtar, Profile of heavy metals in selected medicinal plants, Pakistan Journal of weed Science Research, 14 (1-2) (2008) $101-110$.

[5] R.K. Sharma, M. Agrawal, F.M. Marshall, Heavy metal in vegetables collected from production and market sites of tropical urban area of India, Food and Chemistry Toxicology, 47 (2009) 583 - 591.

[6] Quality Control Methods for Medicinal Fruit Materials (World Health Organization), Geneva, 2005

[7] R. Singh, D.P. Sing, N. Kumar, S.K. Bhargava, S.C. Barman, Accumulation and translocation of heavy metals in soil and plants from fly ash contaminated area, Journal of Environmental Biology, 31 (2010) 421 - 430.

[8] R. Radivojevic, V.N. Bashkin, Practical Environmental Analysis, The Royal of Chemistry, Cambridge 1999, United Kingdom

[9] S. Ercisli, A Short Review of the Fruit Germplasm Resources of Turkey, Geneteic Resources and Crop Evolution, 51 (4) (2004) 419 - 435.

[10] E. Ercisli , E. Orhan, Chemical Composition of White
(Morus alba L.), Red (Morus rubra L.) and Black (Morus nigra L.) Mulberry Fruits, Food Chemistry, 103 (4) (2007) $1380-1384$.

[11] M. Ozgen, S. Serce and K. Kaya, Phytochemical and Antioxidant Properties of Anthocyanin-Rich Morus nigra and Morus rubra Fruits, Scientia Horticulturae, 119 (3) (2009) $275-279$.

[12] S. Ercisli, E. Orhan, Some Physico-Chemical Characteristics of Black Mulberry (Morus nigra L.) Genotypes from Northeast Anatolia Region of Turkey, Scientia Horticulturae, 116 (1) (2008) 41 - 46.

[13] D. Gerasopoulos and G. Stavroulakis, Quality Characteristics of Four Mulberry (Morus Species) Cultivars in the Area of Chania, Greece, Journal of the Science of Food and Agriculturae, 73 (2) (1997) 261- 264.

[14] A. Sass-Kiss, J. Kiss, P. Milotay, M.M. Kerek, M.TothMarkus, Diferences in Anthocyanin and Carotenoid Content of Fruits and Vegetables, Food Research International, 38 (8-9) (2005) 1023 - 1029.

[15] J.Y. Quian, D. Liu and A.G. Huang, The Efficiency of Flavonoids in Polar Extracts of Lycium chinense Mill Fruits as Free Radical Scavenger, Food Chemistry, 87 (2) (2004) 283 - 288.

[16] A. Trappey, H.A. Bawadi, R.R. Bansode and J.N. Losso, Anthocyanin Profile of Mayhaw (Cretaegus opaca), Food Chemistry 91 (4) (2005) 665 - 671.

[17] J.Y. Lin and C.Y.Tang, Determination of Total Phenolic and Flavonoid Contents in Selected Fruits and Vegetables as Well as Their Stimulatory Effects on Mouse Splenocyte Proliferation, Food Chemistry, 101 (2007) 140 - 147.

[18] C. Reimann, A. Arnoldussen, R. Boyd, T.E. Finne, F. Koller, P. Englmaier, Element contents in leaves of four plants species (birch, mountain ash, fern and spruce) along anthropogenic and geogenic concentration gradients. Science of the Total Enviroment, 377 (2007) 426 - 433.

[19] Y. Nahar Jolly, A. Islam, S. Akbar, Transfer of metals from soil to vegetables and possible health risk assessment, SpringerPlus, 2 (2013) 385.

[20] P.M. Guenther, K.W. Dodd, J. Reedy, S.M. Krebs-Smith, Most Americans eat much less than recommended amounts of fruits and vegetables, Journal of American Diet Association, 106 (9) (2006) 1371.

[21] U. S. Environmental Protection Agency (US EPA) Risk Assessment Guidance for Superfund: Human Health Evaluation Manual [part A]: Interim Final (U. S. Environmental Protection Agency, Washington, DC, USA 1989) [EPA/540/1-89/002]

[22] FAO/WHO, Contaminants. In Codex Alimentarius, vol. XVII, Edition 1. FAO/WHO. (Codex Alimentarius Commision, Rome, 1984

[23] Quality Control Methods for Medicinal Plant Materials (World Health Organization, Geneva, 1998)

[24] A. Kabata-Pendias, H. Pendias, Trace Elements in Soils and Plants, 3rd edition (CRC Press, Boca Raton, FL, 2001)

[25] M. Miclean, C. Roman, E. Levei, M. Senila, B. Abraham, E. Cordos, Heavy metals availability for plants in a mining area from North-Western Romania, Research Report, INCDO-INOE 2000, Research Institute for Analytical Instrumentation, Romania, 2000

[26] M.A.G. Maobe, E. Gatebe, L. Gitu and H. Rotich, Profile of heavy metals in selected medicinal plants used for the treatment of diabetes, malaria and pneumonia in Kisii Region, South west Kenya, Global Journal of 
pharmacology, 6 (3) (2012) 245 - 251.

[27] Quality Control Methods for Medicinal Plant Materials (World Health Organization Geneva, 2005)

[28] M. Mehes-Smith, K.K. Nkongolo, R.Narendrula and E.Cholewa, Mobility of heavy metals in plants and soil: A case study from a mining region in Canada, American Journal of Environmental Science, 9 (6) (2013) 483 - 493

[29] A.Shah, A.Niaz, N.Ullah, A.Rehman, M. Akhlaq, M. Zakir and M.S. Khan, Comparative study of heavy metals in soil and selected medicinal plants, Hindawi Publishing Corporation, Journal of Chemistry, (2013) 1-5.

[30] O.G. Davila, J.M. Gomez-Bernal and E.A. Ruiz-Huerta, Plants and soil contamination with heavy metals in agricultural areas of Guadalupe, Zacatecas, Mexico, Environmental Contamination, (2012) 37 - 50.

[31] K.Tahar and B. Keltoum, Effects of heavy metals pollution in soil and plant in the industrial area, West Algeria, Journal of the Korean Chemical Society, 55 (6) (2011) $1018-1023$

[32] O.D. Opaluwa, M.O. Aremu, L.O. Ogbo, K.A. Abiola, I.E. Odbila, M.M. Abubakar and N.O. Nweze, Heavy metal concentration in soils, plant leaves and crops grown around dump sites in Lafia Metropolis, Nasarawa State, Nigeria, Advances in Applied Science Research, 3 (2) (2012) $780-784$

[33] J. Liang, C. Chen, X. Song, Y. Han and Z. Liang, Assessment of heavy metal pollution in soil and plants from Duhnua sewage irrigation area, International Journal of Electrochemical science, 6 (2011) 5314 - 5324.

[34] M. Pehluvan, H. Karlidag and M. Turan, Heavy metal levels of mulberry (Morus alba I.) grown at different distances from the roadsides, The Journal of Animal and Plant Sciences, 22 (3) (2012) 665 - 670.
[35] R.H. Habib, M.A. Salih and Z.M. Muhanad, Toxic heavy metals in soil and some plants in Baghdad, Iraq, Journal of Al-Nahrain University, 15 (2) (2012) 1 - 16.

[36] M.C. Jung, Heavy metal concentrations in soils and factorsaffecting metal uptake by plants in the vicinity of a Korean Cu-W Mine, Sensors, 8 (2008) 2413 - 2423.

[37] W.P. Gardiner, Statistical analysis methods for chemists: a software-based approach (Royal Society of Chemistry, Cambridge, UK, 1997)

[38] L. Friberg, G.F. Nordberg, B. Vpuk, Handbook on the Toxicity of Metals, Elsevier, Bio Medical Press, North Holland, Amsterdam, 1984

[39] Food and Nutritional Board, Recommended Intake for Individuals, Dietary Reference Intakes [DRis], National Academy of Sciences, Washington, DC, USA, 2004

[40] Evaluation of Certain Food Additives and Contaminants. In: Forty-First Report of the joint FAO/WHO Expert Committee on Food Additives. WHO Technical Series, 837 (World Health Organization, Geneva, Switzerland, 1993)

[41] Evaluation of Certain Food Additives and Contaminants. In: Sixty-First Report of the joint FAO/WHO Expert Committee on Food Additives. WHO Technical Series, 922 (World Health Organization, Geneva, Switzerland, 2004)

[42] World Health Organisation (WHO), Evaluation of Certain Food Additives and Contaminants. In: Forty-First Report of the joint FAO/WHO Expert Committee on Food Additives. WHO, Geneva, Switzerland, Technical Series, 837, 1993

[43] Integrated Risk Information System (U. S. Environmental Protection Agency [US EPA], 2010

\section{Izvod}

\section{BIOAKUMULACIJA METALA U RAZLIČITIM VRSTAMA DUDA}

Saša S. Randjelovic, Danijela A. Kostić, Biljana B. Arsić, Gordana Stojanović

(ORIGINALNI NAUČNI RAD)

UDC 546.3:582.635.3:543.4

Univerzitet u NIšu , Prirodno-matematički fakultet, Departman za hemiju, Niš, Srbija

Atomsko absorpcionom spektroskopijom određena je koncentracija Zn, Mn, Fe, $\mathrm{Ni}$, Cu i Cd u uzorcima zemljišta, lišća i plodovima duda (Morus alba L. and Morus nigra L.) sa područja jugoistočne Srbije. Izračunata je translokacija metala iz zemljišta u lišće i plodove, procenjen dnevni unos metala i indeks zdravstvenog rizika. Takođe, utvrđena je i pozitivna korelacija između metala u zemljištu, lišću i plodovima.
Ključne reči: dud, metali, zemljište, lišće, plod 